\title{
Removal efficiency of antibiotics from water through constructed wetlands, a review
}

\author{
Sanjrani Manzoor A. ${ }^{1}$, Ul Ain Bhutto S. ${ }^{2}$, Abodif A.M. ${ }^{3,4}$, Muneer S.A. ${ }^{2}$, Chandio S. ${ }^{2}$ and Gang X. ${ }^{1 *}$ \\ ${ }^{1}$ College of Environmental Science and Engineering, Donghua University, Shanghai, China \\ ${ }^{2}$ School of Environmental Science and Engineering, Tianjin University, China \\ ${ }^{3}$ School of Civil Engineering and Architecture, Wuhan University of Technology, Wuhan, China \\ ${ }^{4}$ Civil Engineering Department, El Minya Higher Institute of Engineering and Technology, AL Minya, Egypt \\ Received: 03/01/2021, Accepted: 06/08/2021, Available online: 15/08/2021 \\ *to whom all correspondence should be addressed: e-mail: xuegang@dhu.edu.cn
}

https://doi.org/10.30955/gnj.003497

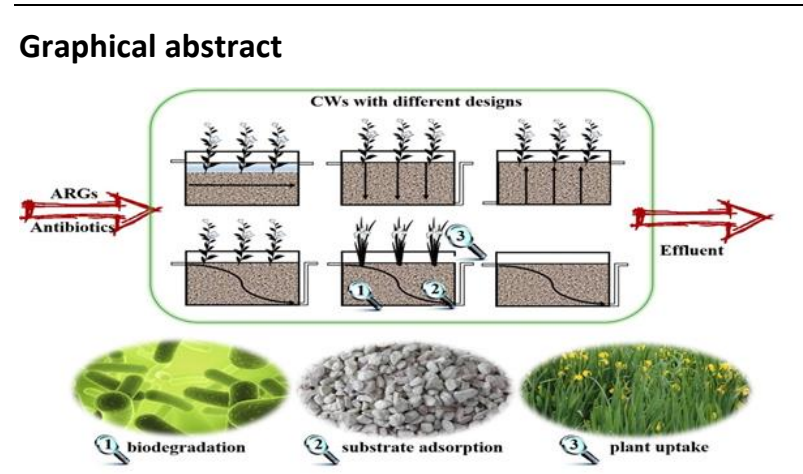

Abstract

Contamination of the aquatic environment with antibiotics and resistance genes is becoming an increasing threat to global health. Overuse of antibiotics has become a serious ecological problem and there is growing concern that antibiotics are losing their effectiveness due to increased antibiotic resistance in bacteria. During the last twenty years, the consumption of antibiotics has increased rapidly, which has been cited as one of the world's worst abusers of antibiotics. Several studies have been conducted to solve this issue. Developed countries have introduced several methods for antibiotic removal, constructed wetlands have been found low cost and easily maintainable technology. Although constructed wetlands (CWs) offer a potential way to remove these antibiotics from water the knowledge of their mechanisms is limited. In this review, we highlight important aspects of antibiotic pollution in the aquatic environment, the removal efficiency of constructed wetlands for antibiotics, and this review highlights antibiotic pollution which affects many things which taken together poses several challenges for environmental scientists. It has been discovered that four main factors are affecting the performance of constructed wetlands used for the treatment of antibiotics in water supplies, the type's configurations of constructed wetlands, hydraulic load rates, substrates, plants, and microorganisms. Further research focusing on these factors are recommended to improve the removal efficiency of antibiotics in constructed wetlands. Outcomes of the study could help wastewater treatment plant engineers with providing reliable design data and outline a road map for future research.

Keywords: Antibiotic contamination, biological degradation, pollutants, water supplies, constructed wetland.

Abbreviations: ARB, Antibiotic resistant bacteria; ARG, Antibiotic resistance gene; AMRs, Antimicrobial resistance; COD, Chemical oxygen demand; CWs, Constructed wetlands; CWTS, Constructed wetland treatment systems; EOCs, Emerging organic contaminants; MSW, Municipal solid waste; OM, Organic matter; TSS, Total suspended solids; TN, Total nitrogen; TP, Total phosphorus; TC, Tetracycline; UV, Ultaviolet; VFCWs, Vertical flow constructed wetland; WWTP, Wastewater treatment plant.

\section{Introduction}

Recently, the effects of antibiotics and other pharmaceuticals on bacterial populations in the environment have got great interest. Though antibiotics have been extensively used in the treatment of humans and animals for various bacterial infections but also have severe effects on the environment (Gao et al., 2012; Huang et al., 2015; Hughes et al., 2013; Zhang et al., 2013). Several studies have identified that several micropollutants are involved in environmental pollution through entering the water bodies because hospital and municipal wastewater treatment plants cannot remove antibiotics (Kraemer et al., 2019; Verlicchi et al., 2012) and pharmaceuticals products from the water properly (Hughes et al., 2013). It has been reported that about half the U.S. population lives without access to safe water (Aydin et al., 2016). In the literature, we found examples of considerable antibiotic pollution in freshwaters (Kraemer et al., 2019; Xue et al., 2013; Zhang et al., 2015; Zhou et al., 2013). In developing countries, wastewater containing several pollutants is released into the environmental bodies without treatment. This extensive practice leads to the contamination of water bodies (John, 2017; Kümmerer, 2009). 
Some amounts of antibiotics and related compounds have been detected in various environmental compartments of treated wastewater (Ahmed et al., 2020), drinking water, groundwater (Vaz-Moreira et al., 2014), surface water, sediments, and soils (Yang, 2017). Untreated sewage from municipal services and hospitals is reported as a major source of such contamination (Nain, 2015). Though conventional wastewater treatment plants (WWTP) are there for the removal and reduction of many pollutants including pathogenic microorganisms, organic matters, and even antibiotics (Boy-Roura et al., 2018; Moges et al., 2014) it seems that proper treatment is required. Conventional wastewater treatment plants (WWTPs) are not designed to remove pharmaceuticals, metabolites, or drugs, documented by some studies (Jurado et al., 2019; Kim et al., 2014; Mcene et al., 2014). Constructed wetlands have been recommended as an efficient technology for the removal of pathogenic and antibiotics. Removal efficiency in CW is more than other technologies because the majority of studies of antibiotics removal via tertiary wastewater treatment have been conducted in EU nations, the USA, Australia, and China, and recently CWs are being implied.

Our study aimed to review the occurrence and the removal efficiency of antibiotics through CWs and to evaluate the short-term effect of environmentally relevant concentrations of antibiotics on the diversity of a CWs bacterial community. Outcomes of the study could help wastewater treatment plant engineers with providing reliable design data and outline a road map for future research.

\section{The occurrence of antibiotics in the aqueous environment}

Antibiotic medicine is one of the most significant scientific discoveries of the 20th century for several diseases in living things. Besides this, antibiotics are potential environmental contaminants also occurrence of antibiotics in the aquatic environment, causes and consequences (Hirsch et al., 1999; Kovalakova et al., 2020; Polianciuc et al., 2020), so the scientific community has great concern about the presence of antibiotic drugs in the environment especially water and soil through a complex vicious cycle of transformation and bioaccumulation (Abuin et al., 2006; Carvalho and Santos, 2016). Worldwide, antibiotic usage exceeds 100,000 tons per year and there is increasing concern over the fate of these substances. Antibiotics are ubiquitous in the environment and significant concentrations have been detected in freshwaters. It is because of not treating wastewater properly (See Figure 1) (Thai et al., 2018).

Studies about antibiotics in different areas around the world demonstrated that water bodies have different kinds of antibiotics. The occurrence of antibiotics as emerging contaminant substances in the aquatic environment is highlighted by environmental scientists (Milić et al., 2013). Antibiotic consumption in livestock reached 63,151 tons in 2010 and is predicted to increase by another $67 \%$ by 2030 (Van Boeckel et al., 2015).
Antibiotic use is also rising in aquaculture, the fastestgrowing food sector worldwide due to intensive farming (Henriksson et al., 2018). Antibiotic concentrations in surface freshwaters reach up to $50 \mu \mathrm{g} / \mathrm{L}$ (Marie-Claire Danner et al., 2019). Antibiotics have been found in the aqueous environment in several countries, even developed countries such as the USA and the European Union. In the literature, we found examples of considerable antibiotic pollution in freshwaters (Zhou et al., 2013). An increase of antibiotic-resistance genes has also been observed in environmental samples from different parts of the world. For example, ARG abundance for all classes of antibiotics was found to be significantly increased in soils from the Netherlands since the 1940s (Knapp et al., 2010). In the Americas, antibiotic concentrations of up to $15 \mu \mathrm{g} / \mathrm{L}$ have been measured. Higher concentrations were reported from European and African studies (over $10 \mu \mathrm{g} / \mathrm{L}$ and $50 \mu \mathrm{g} / \mathrm{L}$ respectively). Antibiotic residue in the aquatic environment, status in Africa are documented in detail (Faleye et al., 2018).

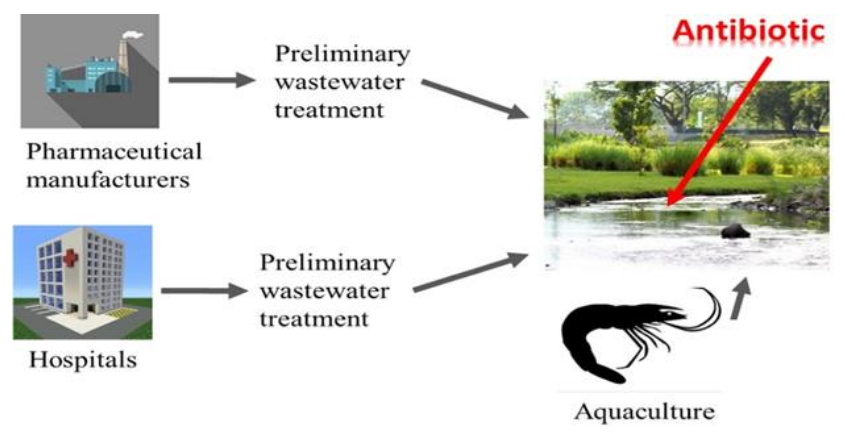

Figure 1. Occurrence of antibiotic and pathways (Modified from: Phong et al. 2018).

In Asian-pacific countries concentrations over $450 \mu \mathrm{g} / \mathrm{L}$ have been detected (Homem and Santos, 2011; MarieClaire Danner et al., 2019). Developing countries such as China where antibiotics have been found in Yangtze river (Zhou et al., 2011), also in other countries such India (Ghafur, 2010), Vietnam (Thuy and Loan, 2011), and most African countries (Olaniran et al., 2009). Khan et al. (2013) demonstrated that antibiotic has been found in water bodies in Pakistan (Khan et al., 2013). A study was conducted, and 19 sampling sites were selected; including one sewage drain, one canal, one dam, four drug formulation facilities, and six rivers; however, Lahore has high levels of antibiotics because of the downstream river (Khan et al., 2013). Hong Kong river water was studied (Deng et al., 2015), the results revealed that the antibiotics were widely distributed in the area studied. Results also showed that ofloxacin was the most frequently detected in the river (Deng et al., 2015).

In Iran, a water treatment plant at the central plateau, based on SPE-LC-MS-MS technology was focused. The study was conducted for a total of five antibiotics used for humans and veterinarians. Results show that ampicillin and ciprofloxacin were present in source water (Heidari et al., 2013). In Iraq, detection of antibiotics in drinking water treatment plants in Baghdad city, Iraq was conducted, the results of this study revealed the existence 
of antibiotic drugs in raw and finished water and should be included in the Iraqi standard for drinking water quality assessment (Mahmood et al., 2019). In Oman, there are no published data specifically on wastewater effluent testing for antibiotics, but several studies were conducted on multiple drug resistance bacteria, which could indicate the presence of antibiotics as well. Mahmoud et al. (Mahmoud et al., 2013) investigated treated wastewater effluent, and results showed that there were multiple antibiotic-resistant bacteria and the most common antibiotics they were resistant are ampicillin (83.3\%) and carbenicillin (66.7\%), and none to sulfamethoxazole. This study documented that the development of antibioticresistant bacteria strains is enhanced by inappropriate use of antibiotics in humans and animals, which could adversely affect the environment (Mahmoud et al., 2013). It is the same as, results of one study also demonstrate that antibiotic resistance genes were functionally diverse before the anthropogenic use of antibiotics, contributing to the evolution of natural reservoirs of resistance genes (Perron et al., 2015). Another study (Al-Bahry et al., 2012) was conducted in Oman and it has demonstrated the most common multiple antibiotic-resistant bacteria resistance to antibiotics mainly ampicillin (100\%), sulfamethoxazole (approx. 95\%), carbenicillin (80\%), followed by streptomycin (approx. 77\%) and the rest of antibiotics (Al-Bahry et al., 2012). It was shown from the above countries that the most common antibiotics found in wastewater plants effluent were macrolides, fluoroquinolones, sulfonamides, and trimethoprim (Karthikeyan and Meyer, 2006; Leung et al., 2012; Lindberg, 2006; Watkinson et al., 2009). In addition, several studies from different countries documented that high consumption of penicillin was there but low or minimal concentrations in effluents (Leung et al., 2012; Lindberg, 2006; Watkinson et al., 2009). This factor can relate to the consumption of the most common antibiotics found in wastewater plant effluents whereas, penicillin was the most commonly used on a global scale, but none of the wastewater plants in the above countries reported its occurrence in high concentration (Jelić et al., 2012; Michael et al., 2013).

Antibiotics such as doxycycline and sulfadimidine were also found at the same level as in rivers in Australia and North America. In Europe including Spain and France also have been confirmed. In China, rivers including the Yangtze and Pearl Rivers have the concentration of the same antibiotic at the same level. In addition, other types of antibiotics were found at lower levels (Liang et al., 2013; Zhang et al., 2015). Antibiotics originated in the environment through different sources including humans, animals, aquaculture, agriculture, and pharmaceutical manufacturers. It is clear that humans are the most consumers of antibiotics and share a huge amount in the environment such as throw in the dustbin, flushing down in the toilets could lead to an accumulation of a hefty amount of drugs in wastewater. In most houses around the world, a bunch of expired medications is stocked in cabinets ends up being flushed into the toilets. Hospital effluent is also rich in antibiotics with higher concentrations (Abuin et al., 2006; Homem and Santos, 2011; Kummerer, 2009; Moges et al., 2014; Priyankaa, 2015). Besides, problems are everywhere around the world, solutions for removal with easily available and lostcost technology need to be introduced.

Even though after treatment, antibiotics still exist in water bodies. One study documented that, quantitative metagenomic and metatranscriptomic approaches to achieve a broad-spectrum view of the flow and expression of genes related to antibacterial resistance to over 20 classes of antibiotics, 65 biocides, and 22 metals. All compartments of 12 WWTPs share persistent resistance genes with detectable transcriptional activities that were comparatively higher in the secondary effluent, where mobility genes also show higher relative abundance and expression ratios (Ju et al., 2019). A study (Lindberg, 2006) was conducted by the chemistry department of Umea University in different parts of Sweden and reported about five different wastewater plants for antibiotics in wastewater effluent. The study results demonstrate that each plant had different antibiotics with different concentrations. The most common antibiotics were found are sulfamethoxazole, fluoroquinolones, ciprofloxacin, ofloxacin, doxycycline, and trimethoprim. Further, it was reported that the usage and consumption of penicillin were the most consumed antibiotics in Sweden (Lindberg, 2006). Another survey (Karthikeyan and Meyer, 2006) was conducted in Wisconsin, USA, where seven wastewater treatment plant effluents were analyzed. The results from this study showed that six different antibiotics in the effluent were detected. The study report found different concentrations in different plants, and they were tetracycline $(0.07-0.37 \mu \mathrm{g} / \mathrm{L})$, trimethoprim $(0.12-$ $0.55 \mu \mathrm{g} / \mathrm{L})$, sulfamethoxazole $(0.05-0.37 \mu \mathrm{g} / \mathrm{L})$, macrolides (approx. $0.3 \mu \mathrm{g} / \mathrm{L}$ ), and fluoroquinolones in the form of ciprofloxacin $(0.04-0.14 \mu \mathrm{g} / \mathrm{L})$. Not surprisingly, concentrations of those antibiotics were higher in the influents in comparison with the effluents. It also noticed that there was a change in concentrations with respect to different seasons (Karthikeyan and Meyer, 2006). Watkinson et al. (Watkinson et al., 2009) investigated five wastewater treatment plant effluents in Queensland, Australia. The study explained the presence of antibiotics in wastewater treatment plant effluents. The study was conducted for effluents to find out a complete list of all antimicrobials that exist there. The study results showed that there were concentrations of fluoroquinolones, macrolides, and sulfonamides ranging from 0.01 to $14.5 \mu \mathrm{g} / \mathrm{L}$. In comparison with the case of Sweden's study, penicillin was the most consumed antibiotic in Australia, but the minimum amount was found in the effluent. The overall extraction of antimicrobials comparing the influent with the effluent was about $80 \%$ by wastewater treatment plants (Watkinson et al., 2009). A study (Leung et al., 2012) was conducted in seven wastewater treatment plant effluents in Hong Kong. Results demonstrated the existence of antibiotics in all those seven treatment plants. The most common antibiotics found were norfloxacin (35-4000 $\mathrm{ng} / \mathrm{L}$ ), fluoroquinolones (ofloxacin in the range of $96-7870 \mathrm{ng} / \mathrm{L}$ ), macrolides 
(erythromycin in the range of $250-4000 \mathrm{ng} / \mathrm{L}$ ), $\beta$-lactams (cefalexin in the range of $180-4000 \mathrm{ng} / \mathrm{L}$ ), sulfamethoxazole $(5-300 \mathrm{ng} / \mathrm{L})$, and trimethoprim (60$450 \mathrm{ng} / \mathrm{L})$. This study discovered that wastewater treatment plants that use different phases of treatments such as primary, secondary, and tertiary have the capacity to increase the removal efficiency (Leung et al., 2012).

\section{Environmental issues from antibiotic and solution approach}

In recent years, antibiotic residues and antibiotic resistance genes (ARGs) in the environment have been recognized as an emerging environmental issue. Researchers indicated that hospital waste which is discharged to the environment is more dangerous than municipal wastewater because it contains higher amounts of antibiotic-resistant bacteria, genes, and residual antibiotics (Andersson and Hughes, 2012; Graham et al., 2016; Nuñez, 2016). In developing countries, the impact of antibiotics on the environment is extremely serious due to misuse, overuse, and damping of antibiotics (Berendonk et al., 2015; Mustapha et al., 2016). Zhou et al. (2013) conducted research in South China on two typical wastewater treatment plants focussing on occurrence and fate of eleven classes of antibiotics. The study described that considerable antibiotic pollution in freshwaters can be found because of not proper treatment (Zhou et al., 2013). Xue et al. (2013) focused on ecotoxicology and environmental safety. Sampling locations were selected in the Yongjiang River. The study demonstrated issues about the occurrence and ecological risks impacted by tributary discharge and anthropogenic activities. Antibiotic contamination in a typical developing city in south China was highlighted (Xue et al., 2013). Zhang et al. (2015) studied on river basins of China, focusing on a comprehensive evaluation of antibiotics emission and fate. The study also focused on source analysis, multimedia modeling, and linkage to bacterial resistance. it was recommended that implementation work is not being done properly and this is the reason that rivers are facing diffierent kinds of pollution including antibiotic pollution (Zhang et al., 2015).

Amarasiri et al. (2019) conducted research on antibioticresistant bacteria (ARB) and antibiotic resistance genes (ARG) in water environments. The study was also focused on understanding human health risks caused by these factors. The study summarizes the current knowledge regarding the $A R B$ and $A R G s$ in aquatic environments and highlights the challenging questions remaining to be answered to better forecast the health risks caused by $A R B$ and ARGs in water environments. Study reviews on several questions to be answered and find a solution, including quantifying the human health risks caused by exposure to ARB and ARGs in aquatic environments, ARG selection, and propagation occur in aquatic environments, and evaluation of the ARB/ARGs contamination in aquatic environments. Studies on the above topics will contribute to better management of antibiotic resistance dissemination in water environments and its risks to human health (Amarasiri et al., 2020). Garcia et al. (2020) reviewed increasing removal with wetlands and reducing environmental impacts, specially focused on emerging organic contaminants (EOCS), antibiotic-resistant bacteria (ARB), and antibiotic resistance genes (ARGs) in the environment. The study highlighted the presence of antibiotic-resistant bacteria in wastewater treatment and the presence of antibiotic resistance genes in the environment (García et al., 2020). The antibiotic issue remained the most important challenge around the globe (Williams et al., 2016) and to human health (See Figure 2) (Williams-Nguyen et al., 2016). In Europe, each year, 25,000 people die directly from drug-resistant bacterial infections. The report was documented by the European Centre for Disease Prevention and Control (Kraemer et al., 2019).

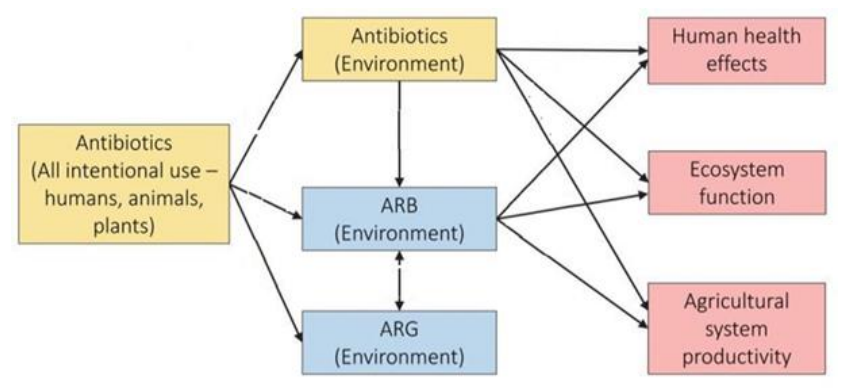

Figure 2. Antibiotic and environmental issues (Modified from Jessica et al., 2016).

European research aims to assess the presence of four antibiotic compounds detected in the influent and effluent of wastewater treatment plants (WWTPs) in the POCTEFA territory (north of Spain and south of France) from 2018 through 2019 and to relate the removal of antibiotic compounds with the processes used in the WWTPs (Moles et al., 2020). Though conventional wastewater treatment plants (WWTP) are there for the removal and reduction of many pollutants including pathogenic microorganisms, organic matters, and even antibiotics (Boy-Roura et al., 2018; Moges et al., 2014). However, these kinds of processes in treatment may have several sources for collection points for resistant organisms and antibiotics. It may be considered as a hotspot site for the dissemination of antibiotics (Priyankaa, 2015), antibiotic-resistant bacteria and genes which can survive long (Mao, 2015), harsh routs and final disinfection processes into surface and drinking waters (Rowe, 2017). Moreover, because antibiotic pollution is poorly regulated on a local and global scale, antibiotic molecules are increasingly found in terrestrial, freshwater, and marine environments (Boy-Roura et al., 2018). Conventional wastewater treatment plants (WWTPs) are not designed to remove pharmaceuticals, metabolites or drugs (Jurado et al., 2019; Kim et al., 2014; Mcene et al., 2014). Some countries are using bio-method of treatment (see Figure 3).

Another approach for antibiotics was conducted for the separation of tetracycline from wastewater using a forward osmosis process with thin-film composite membrane-implications for antibiotics recovery (Pan et al., 2015). In addition, for the solution of antibiotic issues 
with different technologies, study (Alnajrani and Alsager, 2020) was conducted on removal of antibiotics from water by polymer of intrinsic microporosity with isotherms, kinetics, thermodynamics, and adsorption mechanism and results show better removal rate but still need to find easily available technology. Moreover, antibiotics can be removed well with different technologies but also incomplete removal of various antibiotics in conventional municipal WWTPs with variable rates has been documented in some studies (see Table 1). Another study was conducted about the removal of antibiotics in conventional and advanced wastewater treatment, implications for environmental discharge, and wastewater recycling (Watkinson et al., 2007). Proclivities for the prevalence and treatment of antibiotics in the ambient water was studied, different technologies were applied around the world (Bhagat et al., 2020). Constructed wetlands have been documented as an efficient technology for the removal of pathogenic and antibiotics. Removal efficiency is more than other technologies because the majority of studies of antibiotics removal via tertiary wastewater treatment have been conducted in EU nations, the USA, Australia, and China. In comparison, sand filtration and UV irradiation are less effective (Chen et al., 2015; Sanjrani et al., 2019; SidrachCardona and Becares, 2013). Recently, the constructed wetland is being used to treat wastewater.

Table 1. Incomplete removal of various antibiotics in conventional municipal WWTPs

\begin{tabular}{|c|c|c|c|}
\hline S. No & Antibiotics & Percentage & Reference \\
\hline 1 & Sulfadiazine & 23 to $94 \%$ & \multirow{10}{*}{$\begin{array}{l}\text { Chen et al. (2015); Chen et al. (2016); Gao et al. (2012); Hien et al. (2017); Huang et al. } \\
\text { (2015); Jia et al. (2012); Li and Zhang (2010); Lindberg (2006); Liu et al. (2013); Liu et al. } \\
\text { (2014); Xu et al. (2007); Zhou et al. (2013) }\end{array}$} \\
\hline 2 & Chlortetracycline & 78 to $100 \%$ & \\
\hline 3 & Tetracycline & -9 to $97 \%$ & \\
\hline 4 & Norfloxacin & -38 to $93 \%$ & \\
\hline 5 & Doxycycline & 43 to $70 \%$ & \\
\hline 6 & Sulfamethoxazole & 34 to $84 \%$ & \\
\hline 7 & Oxytetracycline & 26 to $97 \%$ & \\
\hline 8 & Ciprofloxacin & 5 to $98 \%$ & \\
\hline 9 & Roxithromycin & 7 to $85 \%$ & \\
\hline 10 & Ofloxacin & 3.2 to $84 \%$ & \\
\hline
\end{tabular}

A study from China investigated the removal of eight antibiotics (norfloxacin, ciprofloxacin, lomefloxacin, ofloxacin, tetracycline, oxytetracycline, erythromycin, roxithromycin) from domestic sewage in CWs of different flow types, substrates, plants, and hydraulic loading rates in two seasons. The results showed that the CWs performed efficiently for treating antibiotic contaminated urban wastewater (Dan et al., 2020). In addition, a detailed study was conducted on pharmaceuticals' removal by constructed wetlands, also critical evaluation and meta-analysis on performance, risk reduction, and role of physicochemical properties on removal mechanisms (Ilyas et al., 2020). This technology can treat water in wastewater effluents depends mostly on the bacteria so it is an important concern regarding constructed wetland for wastewater treatment should be addressed that which environment should be provided for bacteria activation (Chen et al., 2016). Different bacterial taxa mediate some processes such as denitrification, nitrogen-fixation, and ammonia-oxidation and due to the high concentration of antibiotics in the influx, may affect the functionality and water purifying properties of a constructed wetland (Scholz and Lee, 2005). Several studies have been conducted on the water for evaluating wastewater treatment plants and rivers for antibiotic pollution its removal with different techniques but still water bodies have been found to be polluted by the antibiotic. CW is efficient technology, and it is proved by several studies. Following studies have documented occurrence of antibiotic in water bodies and CW is the best and cost-effective option to solve these environmental issues.
Garcia et al. (2020) reviewed about use of various wetland systems to reduce the EOCs and the combination of the wastewater treatment systems with wetland systems is effective. This study also documented that several compounds are not significantly removed in conventional wastewater treatment plants and later they are discharged to the environment. This action presents an increasing threat to both humans and natural ecosystems. Study demonstrated that CWs is an efficient technology for pollutant removal (García et al., 2020). Study by Arshad et al. (2020) was conducted on antibiotics, AMRs, and ARGs: fate in the environment. The study demonstrated that the correlation between ARGs and integrons confirms the elevated levels of antibiotics due to improper discharge through wastewater and livestock runoff. Resistant elements are termed "xenogenetic," which can act as a surrogate for both pollutants and invasive species that can replicate (Arshad and Zafar, 2020).

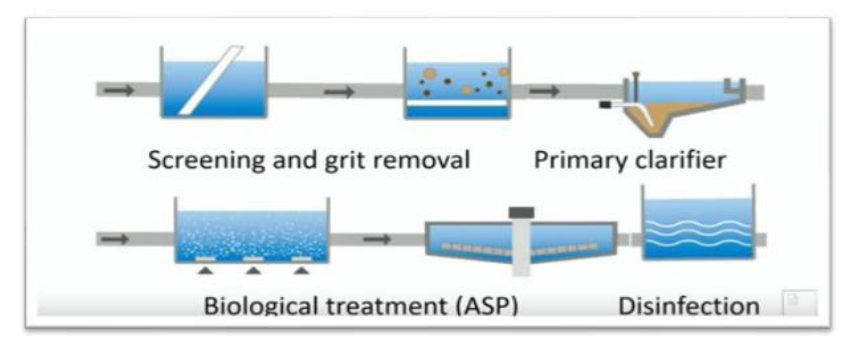

Figure 3. Biological method for water treatment.

Liu et al. (2019) conducted a review study on constructed wetlands for removing antibiotics and antibiotic resistance genes from wastewater also focused on performance and 
microbial response. In this study, different kinds of CWs were analyzed for removing antibiotics and antibiotic resistance genes biodegradation for SAs and MCs, and substrates adsorption for TCs and QNs were main the main removal effect. The study suggested that compared to traditional physical, chemical and biological treatments, constructed wetlands (CWs) is a cost-efficient and ecological technology for the remediation of various kinds of contaminated waters because while summarizing studies from 106 treatment systems from China, Spain, Canada, Portugal for 39 antibiotics removal-related studies also proved that CWs is efficient technology especially vertical flow constructed wetlands (VFCWs). The study also documented that microorganisms are one of the main responsible for antibiotic removal (Liu et al., 2019).

Yujie et al. (2021) described in a review study that for achieving an overall efficient removal of antibiotics in CWTS, our principal component analysis indicated that optimization of flow configuration, selection of plant species, and compensation for low microbial activity at low temperature is the priority strategy. The study was focused on the removal of 35 widely used antibiotics in CWTS covering the most common design parameters (flow configuration, substrate, plants) and operational parameters (hydraulic retention time/hydraulic loading rates, feeding mode, aeration, influent quality), and discusses how to tailor those parameters for improving antibiotic removal based on complex removal mechanisms. The study recommended that to target removal of specific antibiotics, future research should focus on elucidating key mechanisms for their removal to guide optimization of the design and operational parameters (He et al., 2021).

The system can be improved with integrated support from other disciplines, such as botany, soil science, environmental chemistry, and chemical engineering. There are few relevant reports and studies on the removal of antibiotics using CWs, some practical experience of engineering, including the previous researchers' experience in operating chemical reactors (i.e., CWs and soil filters), can also be employed to enhance the performance of CWs for antibiotic treatment at low cost (Liu et al., 2013; Yidong et al., 2017).

\section{Removal of antibiotics from water by constructed wetlands}

Antibiotics are the group of most concern due to the risk of the spread of antibiotic resistance in the environment. The presence of antibiotics in the environment leads to repeated low-dose exposure of bacteria to sub-lethal dosage, which can cause the development of resistance. Considering the problem of antibiotics released in the environment, there is a need for methodologies to efficiently remove these compounds from wastewater. Constructed wetlands are the best alternative for treating wastewater including antibiotic removal from water due to their low costs for construction and operation (Guan et al., 2015; Hijosa-Valsero et al., 2011). Particularly for antibiotics, studies are still scarce. These compounds can cause serious toxic effects in human beings and promote antibiotic resistance, even though antibiotics are normally found at low concentrations in the environment (ng $\mathrm{L}^{-1}$ to $\mu \mathrm{g} \mathrm{L}^{-1}$ ) (Li and Zhang, 2010; Zhang et al., 2014).

From the results of previously published literature, it is concluded that the concentration levels of most detected i.e sulfonamides, quinolones, macrolides, tetracyclines, and lactams (Chen et al., 2016; Dan et al., 2020; Fernandes et al., 2015) have been removed through constructed wetlands (Berglund et al., 2014; Chen et al., 2014; Dires et al., 2018). Constructed wetlands are the best alternative (Carvalho et al., 2013) for treating wastewater including antibiotic removal from water due to their low costs for construction and operation (Chen et al., 2016; Hijosa-Valsero et al., 2011). Several factors are affecting the performance of CWs used for the treatment of antibiotics in water but there are main four things to be mentioned, the types and configurations of CWs, hydraulic load rates, substrates, and plants and microorganisms. Further research focusing on these factors are needed to improve the removal efficiency of antibiotics in CWs (Yidong et al., 2017). The potential of constructed wetlands for pharmaceutical compounds removal from water is also because of the engineered system (Brix and Arias, 2005; Carvalho et al., 2013). Although some researchers have demonstrated that wetland plants are also important for the efficiency of CWs. Xiaoyan et al. (2015) because plants also need to survive in a potentially toxic environment and its variability in the wastewater (Calheiros et al., 2014). Different types of constructed wetlands including integrated CW (Chen et al., 2015), subsurface horizontal flow CW (Chen et al., 2016; Liu et al., 2014), vertical upflow CW (Huang et al., 2015), vertical flow CW (Liu et al., 2013, 2014;) are being used for antibiotic removal and all of them have shown better results (Figure 4).

The removal efficiency of five groups of antibiotics in constructed wetlands has been reported. Those groups: Sulfonamides, Quinolones, Macrolides, Tetracyclines, and B-lactams (Chen et al., 2015; Hijosa-Valsero et al., 2011; Hsieh et al., 2015; Yan et al., 2015). Results from previous studies (Chen et al., 2015; Hijosa-Valsero et al., 2011; Hsieh et al., 2015; Yan et al., 2015), it has been proved that $\mathrm{CW}$ is a good technology for antibiotic removal. Study (Chen et al., 2016) has revealed efficient sulfamethoxazole removal but enhanced the spread of antibiotic resistance genes (Zhang et al., 2020). In addition, some recent years studies have assessed the removal of TC and/or tet genes from wastewater using different types of constructed wetlands including integrated CW (Chen et al., 2015), subsurface horizontal flow CW (Chen et al., 2016; Liu et al., 2014), vertical up-flow CW (Huang et al., 2015), vertical flow CW (Liu et al., 2013, 2014). Vertical subsurface flow CWs showed the highly efficient removal of TC and tet genes from wastewaters. Those mentioned research suggested that adsorption to soil materials might be the primary mechanism for TC removal in constructed wetlands (Liu et al., 2014). In addition, the CWs with lower 
water depth shows to have a higher redox value, as increased redox potential close to the surface correlated with the presence of oxygen, revealing that greater water volume was subject to the enhanced degradation processes that resulted from more intensified molecular oxygen plus the potential benefit of ultraviolet radiation. Substrates in CW systems play dual roles, (i) provide a good environment for plants and microbes to grow well and (ii) remove pharmaceuticals through the coupled effect of biological degradation and absorption.

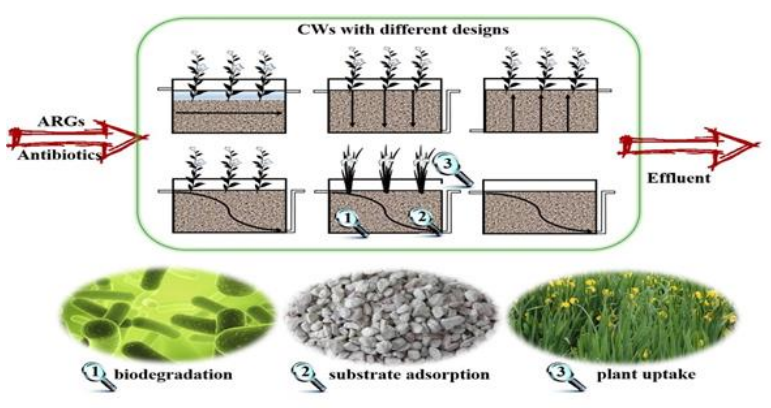

Figure 4. Process of CWs for antibiotic removal (modified from JunChen, 2016).

Previously published studies have documented that various substrates can treat specific antibiotic contaminants. The results show that the substrate utilized in the system can absorb the target antibiotics by capturing them towards the substrate surface under the effect of van der Waals interaction, ion exchange, electronic interaction, and surface complexation (MarieClaire Danner et al., 2019). Among polar pollutants, quinolones show strong absorption on solid substrates containing rich organic matter (OM) and metal oxides ( $\mathrm{Al}$ and Fe hydrous oxides, etc.) (Zhou et al., 2011). Garcia et al. (2020) reviewed about constructed wetlands and their Table 2. Removal mechanisms and wastewater constituents efficiency for pollutant removal. Study demonstrated that constructed wetlands (CWs) have proven effective in removing many EOCs, including different antibiotics, before discharge of treated wastewater into the environment. Wastewater treatment systems that couple conventional treatment plants with constructed and natural wetlands offer a strategy to remove EOCs and reduce antibiotic-resistant bacteria (ARB) and antibiotic resistance genes (ARGs) far more efficiently than conventional treatment alone (García et al., 2020).

In addition, several studies have documented high removal efficiency of antibiotics i.e sulfonamides, quinolones, macrolides, tetracyclines, and lactams range from $-78: 4 \%$ to $100.0 \%, 13.5 \%$ to $100.0 \%,-25: 8 \%$ to $100.0 \%, 47.0 \%$ to $97.0 \%$, and $6.0 \%$ to $45.0 \%$, with mean values of $83.7 \%, 29.2 \%, 70.1 \%, 15.9 \%$, and $51.1 \%$, respectively (Chen et al., 2015; Hijosa-Valsero et al., 2011; Hsieh et al., 2015; Yan et al., 2015). It was reported that vertical subsurface-flow CWs (VSFCWs) and soil filters (multi-soil layering systems) have better capacities for oxygen-diffusion than horizontal subsurface-flow CWs (HSFCWs). This is due to more frequent contact between the solid-liquid interface (Guan et al., 2015), which provides more violently oxidized conditions to degrade pharmaceutical products. In contrast, HSFCWs show signs of inferior conditions inside, reflected by poor ammonia- $\mathrm{N}$ removal usually. Generally during degrading antibiotics, CWs must decrease the contents of nutrients ( $N$ and $P$ ) and other substances in terms of biological oxygen demand (BOD) or chemical oxygen demand (COD). Therefore, an integrated CW, comprising a VSFCW and an HSFCW, may provide a better balance between the removal of $\mathrm{BOD}, \mathrm{N}, \mathrm{P}$, and antibiotics by providing more suitable conditions for biodegrading different contaminants.

\begin{tabular}{|c|c|c|}
\hline $\begin{array}{l}\text { Wastewater } \\
\text { constituents }\end{array}$ & Removal mechanisms & References \\
\hline Heavy metals & Sedimentation, adsorption, plant uptake, chemical precipitation, infiltration & \multirow{13}{*}{$\begin{array}{l}\text { Kataki et al. (2021); } \\
\text { Nuamah et al. (2020); } \\
\text { Parde et al. (2021); } \\
\text { Sanjrani et al. (2019); Tang } \\
\text { et al. (2020); Wang et al. } \\
\text { (2021); Wu et al. (2015); } \\
\text { Zhao et al. (2020) }\end{array}$} \\
\hline Bacteria/pathogens & Sedimentation, natural die off & \\
\hline Synthetic organics & Sedimentation, adsorption, oxidation, volatilization, infiltration & \\
\hline Hydrocarbons & Bio-filtration, microbial decomposition, oxidation, plant uptake metabolism & \\
\hline Total phosphorus & Matrix sorption, plant uptake, sedimentation bio-filtration & \\
\hline Nitrate & $\begin{array}{l}\text { Denitrification } \\
\end{array}$ & \\
\hline Nitrite & Denitrification & \\
\hline Ammonia & Nitrification & \\
\hline $\begin{array}{l}\text { Biological oxygen } \\
\text { demand }\end{array}$ & Sedimentation, bio-filtration & \\
\hline Chemical oxygen demand & Sedimentation, bio-filtration, oxidation & \\
\hline Suspended solids & Sedimentation, filtration & \\
\hline Soluble organics & Aerobic microbial degradation, anaerobic microbial degradation & \\
\hline Total nitrogen & $\begin{array}{l}\text { Ammonification followed by microbial nitrification, denitrification, plant } \\
\text { uptake, matrix adsorption, ammonia volatilization }\end{array}$ & \\
\hline
\end{tabular}

Moreover, Tetracyclines and Sulfonamides are typical amphoteric compounds and mostly their relative hydrophobicity depends upon the organic content and the $\mathrm{pH}$ of the substrate (Dires et al., 2018). It was demonstrated that a substrate with high OM content helps to reduce the potential leachability of tetracyclines and sulfonamides. Macrolides with hydroxyl groups present a medium degree of absorption affinity to soil with high mineral content, and their leachability is limited (Aydin et al., 2016). In addition, the OM content generally 
increases the absorption of antibiotics because of the interaction between the organic groups (carboxyl and phenolic groups), ion exchange, and hydrogen bonding of the substrate matrix with the polar groups of the antibiotics. Therefore, substrates with high OM content, such as compost, soils, and compost/ soil mixtures, have been applied to remove tetracyclines, sulfonamides, salinomycin, quinolones, and tylosin (Al-Farsi et al., 2018; Carvalho and Santos, 2016; Zhou et al., 2013). There are many mechanisms involved in the wetlands system. Removal mechanisms and wastewater constituents are described in Table 2. All mechanisms involved in the system can remove pollutants near $100 \%$. Hence, the removal of antibiotics from water by CWs has been recommended because it's efficient and low-cost technology.

\section{Role of microbial communities and plants in constructed wetlands for antibiotics removal}

Microorganisms play a vital role in treating wastewater in different types of a wastewater systems. Several studies were carried out for the potential of constructed wetlands for pharmaceutical compounds removal from water (Brix and Arias, 2005; Carvalho et al., 2013; Ma et al., 2018). Study on microbial population dynamics in constructed wetlands, a detailed review of recent advancements for wastewater treatment was concluded and it was demonstrated that microbial population is an important factor in CWs (Rajan et al., 2019). Constructed wetlands and phytoremediation are known as a tool for pharmaceutical removal (Carvalho, 2021). A study was conducted on removing antibiotics and antibiotic resistance genes from wastewater by constructed wetlands, performance and microbial response, the importance of microbial communities has been documented (Liu et al., 2019). The efficiency of constructed wetlands in treating E. coli bacteria present in livestock wastewater was studied and it was evident from the study that constructed wetlands are effective in the treatment of E. coli bacteria wetland plants that are used for treatment (Rajan et al., 2020). Characterization of microbial communities in Pilot-Scale constructed wetlands with Salicornia for treatment of marine aquaculture effluents was studied and from a microorganism perspective, the findings of this study could contribute to better understanding of contaminants' removal mechanism and improved management of CWs for treatment of effluents from land-based marine aquaculture (Ma et al., 2018). In addition, the functionality of microbial communities in constructed wetlands used for pesticide remediation and the influence of system design and sampling strategy were studied. The functionality of the biofilm microbial community was positively correlated to the removal of all pollutants (TN, $\mathrm{NH}_{4}{ }^{+}-\mathrm{N}, \mathrm{TP}, \mathrm{TOC}$, and tebuconazole) for both unsaturated and saturated CWs, suggesting the biofilm plays a more important role in pollutant removal than the interstitial water microbial community. Thus, merely observing the interstitial water microbial communities may underestimate the role of the microbial community in $\mathrm{CW}$ performance. Interestingly, the ability for the biofilm microbial community to utilize amino acids and amines/amides was positively correlated with tebuconazole removal in all system types (Lv et al., 2017).

Microbial communities, as well as bacterial diversity present in the environment, are susceptible to antibiotics effects (Ollivier et al., 2013; Hammesfahr et al., 2011). Also, antibiotics affect selectively various groups of microbes, especially antibiotics designed to be broadspectrum drugs (Ding and $\mathrm{He}, 2010$ ). In microbial communities, the effects of antibiotics generally depend on existing antibiotics concentrations, microbial groups, and soil properties (Ding and He, 2010). In fact, it has been reported that selected pressure on soil microbial communities by antibiotics at trace concentrations should be noticed (Thiele-Bruhn and Beck, 2005). There is an increasing body of evidence documenting a reduction of bacterial diversity in soils contaminated with antibiotics (Jechalke et al., 2014; Ollivier et al., 2013). Moreover, it has been documented that veterinary antibiotics effects on the structure and functionality of soil microbial communities at a considerable level (Jechalke et al., 2014). For instance, several changes in the structure of microbial community after application of manure containing sulfadiazine in soils have been observed, also an effect that increased over time (Hammesfahr et al., $2008,2011)$. In addition, effects of slurry from sulfadiazine and difloxacin medicated pigs on soil microbial communities were also detected (Reichel et al., 2013). Obtained results indicated CWs microbial communities were able to adapt to drug presence without significant changes in bacterial abundance, richness, and diversity.

Moreover, the effects of antibiotics on microbial community structure and microbial functions in constructed wetlands treated with artificial root exudates, which may further reveal the ecological implication of plants in constructed wetlands (Tong et al., 2020). Although some researchers have demonstrated that the importance of wetland plants is negligible during the process of antibiotic treatment in CWs. Xiaoyan et al., (2015). With detailed research for current and new perspectives, the role of plants in a constructed wetland was reviewed. Results description is given, in which plants can affect CW processes (Shelef et al., 2013). No doubt, plants play a vital role in water clean-up in constructed wetlands (Ahmed et al., 2020). Two novel functions for plants in CWs were suggested. The first is salt phytoremediation by halophytes. Strong evidence was given that halophytic plants can reduce wastewater salinity by accumulating salts in their tissues. Study (Shelef et al., 2013) has shown that Bassia indica, a halophytic annual, is capable of salt phytoremediation, accumulating sodium to up to $10 \%$ of its dry weight. The second novel use of plants in CWs is as phytoindicators of water quality (Shelef et al., 2013). Plants' involvement in the input of oxygen into the root zone, in the uptake of nutrients, and the direct degradation of pollutants has been documented (Stottmeister et al., 2003; Wang et al., 2016). However, plants also need to survive in a potentially toxic 
environment and its variability in the wastewater (Calheiros et al., 2014). For instance, enrofloxacin phytotoxicity to several crop plants (Phaseolus vulgaris, Cucumis sativus, Lactuca sativa, and Raphanus sativus) is known to be related to plant drug uptake (Fatta-Kassinos et al., 2011). A researcher (Fernandes et al., 2015) recommended that plants can boost soil enzyme activity by excreting exogenous enzymes and can affect microbial communities' composition, structure, and diversity (Fernandes et al., 2015). However, pharmaceutical phytotoxicity is also possible because of pharmaceutical toxicity to soil microorganisms which may affect plantmicroorganism symbiosis (Carvalho et al., 2014; Herklotz et al., 2010). An important factor that has to be considered about plant phytotoxicity is that in subsurface flow CWs, the compound bioavailability for uptake usually readily available from solution but less available due to subtracting interactions in the system (Carvalho et al., 2014; Peng et al., 2014). Studies show the result that three aquatic tropical plants (Canna indica, Phragmites australis and Sacciolepis africana) can be planted effectively. Some aquatic plants used in constructed wetlands are: Lemna valdiviana, Spirodela sp., Typha angustifolia, Typha domingensis, Typha latifolia, Cyperus involucratus, Cyperus giganteus, Thalia dealbata, Cyperus giganteus, Juncus effuses, Phragmites communis, Sagittaria lancifolia are the best players in CWs (Sandoval et al., 2019; Vymazal, 2011, 2013). Study (Vymazal, 2011) concluded that the most commonly used species are robust species of emergent plants, such as the cattail (Typha latifolia), common reed (Phragmites australis), and bulrush.

\section{The risk-on humans and risk management}

The reuse of treated wastewater effluent for irrigation is a common practice in several countries especially not developed countries. Certainly, the reuse of treated wastewater effluent contaminated with multiple antibiotic-resistant bacteria will also reach in crops field and this could harm the end-user of these vegetables or fruits (Al-Bahry et al., 2012; Al-Farsi et al., 2018). Reuse of treated wastewater effluent for agriculture growth generally reaches the crops through root uptake. A study by a researcher ( $\mathrm{Wu}$ et al., 2012) has described that spinach and lettuce are the most vegetables that uptake pharmaceuticals as well as those personal care products from reusing treated wastewater effluents used in irrigation (Wu et al., 2012). From the pharmaceutical's detection, The sulfamethoxazole was detected at a lower limit but another one namely trimethoprim antibiotic that had an uptake with detected concentrations of $1.1 \pm(0.2-$ 0.4) (ng/G dry weight) in both lettuce and spinach. It mostly belongs to those vegetables or fruits that are eaten raw or uncooked and it should be carefully used to avoid health issues and deep studies are being conducted about this issue in the country (Figure 5) (Wu et al., 2012).

In addition, livestock products that are polluted by antibiotics could result in harmful effects on humans. Medically reported that it is harmful as allergic reactions or anaphylaxis, and disturbing the microflora residing in the gastrointestinal tract. A proper withdrawal time should be kept to avoid having those pollutants in the meat before slaughtering the animal. Another mechanism in which resistance could occur was demonstrated that antibiotics in wastewater extensively (Kadim, 2014; Kümmerer, 2008), and has seen that the amount of antibiotics eventually reaches the environment which is in the range of $\mathrm{ng} / \mathrm{L}$ to $\mu \mathrm{g} / \mathrm{L}$, which is thought to be negligible, but little is known about the fate of metabolites and how it affects humans. The low dose and long-term effect of medications or antibiotics in wastewater eventually reused in agriculture and reaching humans by consumption are also not known. There are a few recommendations that consequences of babies, fetuses, and the elderly should also be considered and studied (Kümmerer, 2008). The occurrence of subtherapeutic doses of antibiotics on bacteria over a prolonged period leads to resistance, which is a threat to the environment (Al-Bahry et al., 2012).

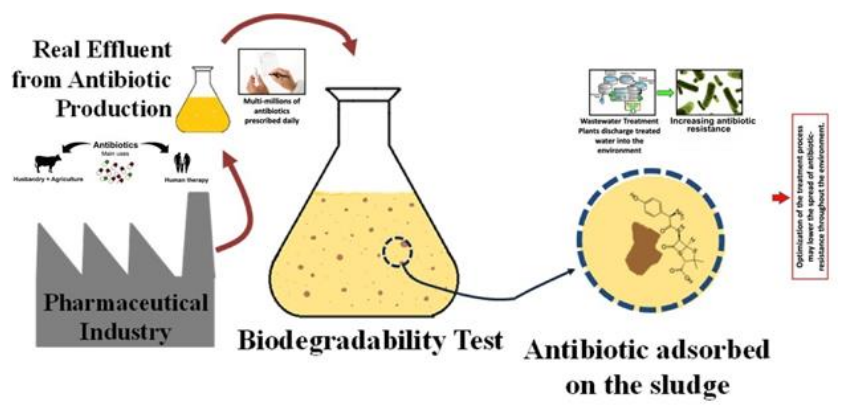

Figure 5. Overall Process for Antibiotic to the environment.

It was demonstrated that the antiepileptic carbamazepine had a significant and specific chronic effect against the oligochaete Chironomus at environmentally relevant concentrations (Oetken et al., 2005). This is further highlighted in the previously published study (Flaherty and Dodson, 2005) that chronic fluoxetine exposure at a low concentration significantly increased the daphnia fecundity. There is a poor understanding of the risks and effects that the pharmaceuticals and their metabolites implications. To avoid the flushing of unused medications, city management has taken steps to reduce risk and they are returning medications to pharmacies. Another method of minimizing the amount of pharmaceuticals in the wastewater is to have advanced effluent treatment plants. Also, prescribing awareness should be done such as the overuse of antibiotics in viral infections (Kümmerer, 2008).

\section{Conclusion and recommendations}

Antibiotics have been found in treated wastewater effluent in different countries. Water treatment is not a well-researched process, but recent studies show that many treatment processes allow the reintroduction of antibiotics, antibiotic resistance genes, and resistant organisms back into the environment. Detailed studies are required to be conducted. In this review, important aspects of antibiotic pollution in waters, the removal efficiency of CWs for antibiotic removal, and that 
antibiotic pollution affect many things which taken together poses several challenges for environmental scientists are highlighted. It has been discovered that four main factors are affecting the performance of CWs used for the treatment of antibiotics in water supplies, the types of configurations of CWs, hydraulic load rates, substrates, plants, and microorganisms. From several previously published studies reported that $\mathrm{CW}$ is better technology for antibiotic removal from water. However, there is a research and data gap on antibiotics and a need to investigate more as industrialization and urbanization are changing the world every day and creating different water issues. Constructed wetlands may not treat highly toxic modern wastewater till it is pre-treated in special installations. In climates with cold winters, bacteria and plants living in the constructed wetland's soil die back and release their own nutrients back into the system. A constructed wetland's biological processes are not well understood. Residual pollutants may harm the reserve's wildlife. Hence, more research is required, especially to study the effluents and their analysis for the concentration of antibiotics. In addition, this review also suggests investigating more advanced technologies, such as photo-catalysis and nanotechnology in wastewater treatment plants to get rid of antibiotics, which can eventually harm the environment, humans, and animals. Further, the development of guidelines is crucial in amounts of antibiotics acceptably occurring in treated wastewater effluent and if they could be suitable for agriculture without causing any harm. CWs should include different types of plants and activated carbon fiber to get better results. It is recommended that before selection of plants for wetlands; consider the condition such as weather of the area, type of wetlands, and type of water needs to be treated so that removal percentage should be higher. The addition of biochar/ACF boosts the efficiency of the system. It is recommended that select an efficient material for media. Wood biochar is less expensive than others.

\section{Acknowledgments}

This study is funded by China Postdoctoral Science Foundation

\section{References}

Abuin S., Codony R., Compañó R., Granados M. and Prat M.D. (2006). Analysis of macrolide antibiotics in river water by solid-phase extraction and liquid chromatography-mass spectrometry. Journal of Chromatography. A, 73-81.

Ahmed S.M., Zhou B., Zhao H., Zheng Y.P., Wang Y. and Xia S. (2020). Developing a composite vertical flow constructed wetlands for rainwater treatment. Membrane and Water Treatment, 1-11.

Al-Bahry S.N., Mahmoud I.Y. and Al-Musharafi S.K. (2012). Antibiotic resistant bacteria used as bioindicators of environmental pollution produced by tertiary treated sewage effluent. WIT Transactions on Ecology and the Environment, 313-321.

Al-Farsi R., Ahmed M., Al-Busaidi A. and Choudri B.S. (2018). Assessing the presence of pharmaceuticals in soil and plants irrigated with treated wastewater in Oman. International
Journal of Recycling of Organic Waste in Agriculture, 165172.

Alnajrani M.N. and Alsager O.A. (2020). Removal of Antibiotics from Water by Polymer of Intrinsic Microporosity: Isotherms, Kinetics, Thermodynamics, and Adsorption Mechanism. Scientific Reports, 10(1), 794.

Amarasiri M., Sano D. and Suzuki S. (2020). Understanding human health risks caused by antibiotic resistant bacteria (ARB) and antibiotic resistance genes (ARG) in water environments: Current knowledge and questions to be answered. Critical Reviews in Environmental Science and Technology, 50, 2016-2059.

Andersson D.I. and Hughes D. (2012). Evolution of antibiotic resistance at non-lethal drug concentrations. Drug Resistance Updates, 15(3), 162-172.

Arshad M. and Zafar R. (2020). Chapter 9 - Antibiotics, AMRs, and ARGs: fate in the environment, in Antibiotics and Antimicrobial Resistance Genes in the Environment, M.Z. Hashmi, Editor. Elsevier. p. 138-154.

Aydin S., Ince B. and Ince O. (2016). Assessment of anaerobic bacterial diversity and its effects on anaerobic system stability and the occurrence of antibiotic resistance genes. Bioresource Technology, 332-338.

Berendonk T.U., et al. (2015). Tackling antibiotic resistance: the environmental framework. Nature Reviews Microbiology, 13(5), 310-317.

Berglund B., Khan G.A., Weisner S.E., Ehde P.M., Fick J. and Lindgren P.E. (2014). Efficient removal of antibiotics in surface-flow constructed wetlands, with no observed impact on antibiotic resistance genes. Science of the Total Environment.

Bhagat C., et al. (2020). Proclivities for prevalence and treatment of antibiotics in the ambient water: a review. npj Clean Water, 3(1), 42.

Boy-Roura M., et al. (2018). Towards the understanding of antibiotic occurrence and transport in groundwater: Findings from the Baix Fluvià alluvial aquifer (NE Catalonia, Spain). Science of the Total Environment, 612, 1387-1406.

Brix H. and Arias C.A. (2005). The use of vertical flow constructed wetlands for on-site treatment of domestic wastewater: new Danish guidelines. Ecological Engineering , 491-500.

Calheiros C.S., Rangel A.O. and Castro PM. (2014). Constructed wetlands for tannery wastewater treatment in Portugal: ten years of experience. International Journal of Phytoremediation, 859-870.

Carvalho I.T. and Santos L. (2016). Antibiotics in the aquatic environments: A review of the European scenario. Environment Internatonal, 736-757.

Carvalho P.N., Araújo J.L., Mucha A.P., Basto M.C. and Almeida C.M. (2013). Potential of constructed wetlands microcosms for the removal of veterinary pharmaceuticals from livestock wastewater. Bioresource Technology, 412-416.

Carvalho P.N., Basto M.C., Almeida C.M. and Brix H. (2014). A review of plant-pharmaceutical interactions: from uptake and effects in crop plants to phytoremediation in constructed wetlands. Environmental Science and Pollution Research, 1729-11763.

Carvalho P.N. (2021). Constructed Wetlands and Phytoremediation as a Tool for pharmaceutical removal, in Interaction and fate of pharmaceuticals in soil-crop systems: 
the impact of reclaimed wastewater, S. Pérez Solsona, et al., Editors. Springer Int. Publishing: Cham. p. 377-413.

Chen J., Liu Y.S., Su H.C., Ying G.G., Liu F., Liu S.S., He L.Y., Chen Z.F., Yang Y.Q. and Chen F.R. (2015). Removal of antibiotics and antibiotic resistance genes in rural wastewater by an integrated constructed wetland. Environmental Science and Pollution Research, 1794-1803.

Chen J., Liu Y.S., Su H.C., Ying G.G., Liu F., Liu S.S., He L.Y., Chen Z.F., Yang Y.Q. and Chen F.R. (2014). Removal of antibiotics and antibiotic resistance genes in rural wastewater by an integrated constructed wetland, 2800-2804.

Chen J., Ying G.G., Wei X.D., Liu Y.S., Liu S.S., Hu L.X., He L.Y., Chen Z.F., Chen F.R. and Yang Y.Q. (2016). Removal of antibiotics and antibiotic resistance genes from domestic sewage by constructed wetlands: Effect of flow configuration and plant species. Science of The Total Environment, 571, 974-982.

Chen J., Wei X.D., Liu Y.S., Ying G.G., Liu S.S., He L.Y., Su H.C., Hu L.X., Chen F.R. and Yang Y.Q. (2016). Removal of antibiotics and antibiotic resistance genes from domestic sewage by constructed wetlands: Optimization of wetland substrates and hydraulic loading. Science of the Total Environment, 240-248.

Dan A., Zhang X., Dai Y., Chen C. and Yang Y. (2020). Occurrence and removal of quinolone, tetracycline, and macrolide antibiotics from urban wastewater in constructed wetlands. Journal of Cleaner Production, 252.

Deng W., Li N., Zheng H. and Lin H. (2015). Occurrence and risk assessment of antibiotics in river water in Hong Kong. Ecotoxicology and Environmental Safety.

Ding C. and He J. (2010). Effect of antibiotics in the environment on microbial populations. Applied Microbiology and Biotechnology, 925-941.

Dires S., Birhanu T., Ambelu A. and Sahilu G. (2018). Antibiotic resistant bacteria removal of subsurface flow constructed wetlands from hospital wastewater. Journal of Environmental Chemical Engineering.

Faleye A.C., et al. (2018). Antibiotic residue in the aquatic environment: status in Africa. Journal of Open Chemistry (Weinheim an der Bergstrasse, Germany), 16(1), 890-903.

Fatta-Kassinos D., Kalavrouziotis I.K., Koukoulakis P.H. and Vasquez M.I. (2011). The risks associated with wastewater reuse and xenobiotics in the agroecological environment. Science of the Total Environment, 3555-3563.

Fernandes J.P., Almeida C.M., Pereira A.C., Ribeiro I.L., Reis I. and Carvalho P. (2015). Microbial community dynamics associated with veterinary antibiotics removal in constructed wetlands microcosms. Bioresource Technology, 26-33.

Flaherty C.M. and Dodson S.I. (2005). Effects of pharmaceuticals on Daphnia survival, growth, and reproduction. Chemosphere, 200-207.

Gao L., Shi Y., Li W., Niu H. and Liu J. (2012). Occurrence and fate of quinolone and fluoroquinolone antibiotics in a municipal sewage treatment plant. Water Research, 387-394.

Gao L., et al. (2012). Occurrence of antibiotics in eight sewage treatment plants in Beijing, China. Chemosphere, 86(6), 665671.

García J., et al. (2020). A review of emerging organic contaminants (EOCS). antibiotic resistant bacteria (ARB). and antibiotic resistance genes (ARGs) in the environment:
Increasing removal with wetlands and reducing environmental impacts. Bioresource Technology, 307, 123228.

Ghafur A. (2010). An obituary-on the death of antibiotics. Journal of the Association of Physicians of India, 143144.

Graham D.W., et al. (2016). Appearance of $\beta$-lactam resistance genes in agricultural soils and clinical isolates over the 20th century. Scientific Reports, 6, 21550.

Guan Y., Zhang Y., Zhong C.N., Huang X.F., Fu J. and Zhao D. (2015). Effect of operating factors on the contaminants removal of a soil filter: multi-soil-layering system. Environmental Earth Sciences, 2679-2686.

Hammesfahr U., Kotzerke A., Lamshöft M., Wilke B.M., Kandeler E. and Thiele-Bruhn S. (2011). Effects of sulfadiazinecontaminated fresh and stored manure on a soil microbial community. European Journal of Soil Biology, 61-68.

Hammesfahr U., Kotzerke A., Lamshöft M., Wilke B.M., Kandeler E. and Thiele-Bruhn S. (2011). Effects of sulfadiazinecontaminated fresh and stored manure on a soil microbial community. European Journal of Soil Biology, 61-68.

Hammesfahr H.H., Manzke B., Smalla K. and Thiele-Bruhn S. (2008). Impact of the antibiotic sulfadiazine and pig manure on the microbial community structure in agricultural soils. Soil Biology and Biochemistry, 1583-1591.

He Y., et al. (2021). Improving removal of antibiotics in constructed wetland treatment systems based on key design and operational parameters: A review. Journal of Hazardous Materials, 407, 124386.

Heidari M., Kazemipour M., Bina B., Ebrahimi A., Ansari M., Ghasemian M. and Amin M.M. (2013). A qualitative survey of five antibiotics in a water treatment plant in central plateau of Iran. Journal of Environmental and Public Health.

Henriksson P.J.G., et al. (2018). Unpacking factors influencing antimicrobial use in global aquaculture and their implication for management: a review from a systems perspective. Sustainability Science, 13(4), 1105-1120.

Herklotz P.A., Gurung P., Heuvel B.V. and Kinney C.A. (2010). Uptake of human pharmaceuticals by plants grown under hydroponic conditions. Chemosphere, 1416-1421.

Hien P.T., Tadashi T. and Kazuhiro M. (2017). Removal of tetracycline and tetracycline resistance genes from municipal wastewater in microcosm fill-and-drain constructed wetlands. Japanese Journal of Water Treatment Biology, 11-21.

Hijosa-Valsero M., Fink G., Schlüsener M.P., Sidrach-Cardona R., Martín-Villacorta J., Ternes T. and Bécares E. (2011). Removal of antibiotics from urban wastewater by constructed wetland optimization. Chemosphere, 713-719.

Hirsch R., et al. (1999). Occurrence of antibiotics in the aquatic environment. Science of the Total Environment, 225(1), 109118.

Homem V. and Santos L. (2011). Degradation and removal methods of antibiotics from aqueous matrices-A review. Journal of Environmental Management, 2304-2347.

Hsieh C.Y., Liaw E.T. and Fan K.M. (2015). Removal of veterinary antibiotics, alkylphenolic compounds, and estrogens from the Wuluo constructed wetland in southern Taiwan. Journal of Environmental Science and Health, Part A, 151-160.

Huang X., Liu C., Li K., Su J., Zhu G. and Liu L. (2015). Performance of vertical up-flow constructed wetlands on swine 
wastewater containing tetracyclines and tet genes. Water Research, 109-117.

Hughes S.R., Kay P. and Brown L.E. (2013). Global synthesis and critical evaluation of pharmaceutical data sets collected from river systems. Environmental Science Technology, 661-77.

llyas H., Masih I. and van Hullebusch E.D. (2020). Pharmaceuticals' removal by constructed wetlands: a critical evaluation and meta-analysis on performance, risk reduction, and role of physicochemical properties on removal mechanisms. Journal of Water and Health, 18(3) 253-291.

Jechalke S., Heuer H., Siemens J., Amelung W. and Smalla K. (2014). Fate and effects of veterinary antibiotics in soil. Trends in Microbiology, 22, 536-545.

Jelić A., Gros M., Petrović M., Ginebreda A. and Barceló D. (2012). Occurrence and elimination of pharmaceuticals during conventional wastewater treatment. In: Guasch $\mathrm{H}$., Ginebreda A. and Geiszinger A (eds) Emerging and priority pollutants in rivers. Berlin: Springer - The handbook of environmental chemistry.

Jia A., Wan Y., Xiao Y. and Hu J. (2012). Occurrence and fate of quinolone and fluoroquinolone antibiotics in a municipal sewage treatment plant. Water Research, 387-394.

John. (2017). Wastewater the untapped resource. The United Nations World Water Development Report. FACTS and FIGURES. UNWWDR.

Ju F., et al. (2019). Wastewater treatment plant resistomes are shaped by bacterial composition, genetic exchange, and upregulated expression in the effluent microbiomes. The ISME Journal, 13(2), 346-360.

Jurado A., Walther M. and Díaz-Cruz M.S. (2019). Occurrence, fate and environmental risk assessment of the organic microcontaminants included in theWatch Lists set by EU Decisions 2015/495 and 2018/840 in the groundwater of Spain. Science of the Total Environment, 663, 285-296.

Kadim T. (2014). Chemical contaminates of meat and meat products, which threaten human health. idosi.

Karthikeyan K.G. and Meyer M.T. (2006). Occurrence of antibiotics in wastewater treatment facilities in Wisconsin, USA. Science of the Total Environment, 196-207.

Kataki S., et al. (2021). Constructed wetland, an eco-technology for wastewater treatment: A review on types of wastewater treated and components of the technology (macrophyte, biolfilm and substrate). Journal of Environmental Management, 283, 111986

Khan G.A., Berglund B., Khan K.M., Lindgren P.E. and Fick J. (2013). Occurrence and abundance of antibiotics and resistance genes in rivers, canal and near drug formulation facilities - a study in Pakistan. PLOS ONE.

Kim S., Lieberman T.D. and Kishony R. (2014). Alternating antibiotic treatments constrain evolutionary paths to multidrug resistance. Proceedings of the National Academy of Sciences of the United States of America, 111(40), 1449414499.

Knapp C.W., et al. (2010). Evidence of increasing antibiotic resistance gene abundances in archived soils since 1940 Environmental Science \& Technology, 44, 580-587.

Kovalakova P., et al. (2020). Occurrence and toxicity of antibiotics in the aquatic environment: A review. Chemosphere, 251, 126351.
Kraemer S.A., Ramachandran A. and Perron G.G. (2019). Antibiotic pollution in the environment: from microbial ecology to public policy. Microorganisms, 7(6), 180

Kümmerer K. (2009). Antibiotics in the aquatic environment--a review--part II. Chemosphere, 75(4), 435-441.

Kümmerer. (2008). Pharmaceuticals in the environment - a brief summary. Berlin: Springer.

Kummerer. (2009). The presence of pharmaceuticals in the environment due to human use-present knowledge and future challenges. Journal of Environmental Management, 2354-2366

Leung H.W., Minh T.B., Murphy M.B., Lam J.C., So M.K., Martin M., Lam P.K. and Richardson B.J. (2012). Distribution, fate and risk assessment of antibiotics in sewage treatment plants in Hong Kong, South China. Environment International.

Li B. and Zhang T. (2010). Biodegradation and adsorption of antibiotics in the activated sludge process. Environmental Science Technology, 3468-3473.

Liang X., Chen B., Nie X., Shi Z., Huang X. and Li X. (2013). The distribution and partitioning of common antibiotics in water and sediment of the Pearl River Estuary, South China. Chemosphere, 1410-1416.

Lindberg. (2006). Determination of antibiotics in the swedish environment with emphasis on sewage treatment plants. Umea: Umeå university, Umea, Sweden, Environmental chemistry, Department of chemistry.

Liu L., Liu C., Zheng J., Huang X., Wang Z., Liu Y. and Zhu G. (2013). Elimination of veterinary antibiotics and antibiotic resistance genes from swine wastewater in the vertical flow constructed wetlands. Chemosphere, 1088-1093.

Liu L., Liu Y.H. Wang Z., Liu C.X., Huang X. and Zhu G.F. (2014). Behavior of tetracycline and sulfamethazine with corresponding resistance genes from swine wastewater in pilot-scale constructed wetlands. Journal of Hazardous Materials, 304-310.

Liu X., et al. (2019). A review on removing antibiotics and antibiotic resistance genes from wastewater by constructed wetlands: Performance and microbial response. Environmental Pollution, 254(Pt A), 112996.

Lv T., et al. (2017). Functionality of microbial communities in constructed wetlands used for pesticide remediation: Influence of system design and sampling strategy. Water Research, 110, 241-251.

Ma X., et al. (2018). Characterization of microbial communities in pilot-scale constructed wetlands with Salicornia for treatment of marine aquaculture effluents. Archaea (Vancouver, B.C.), 2018, 7819840.

Mahmood A.R., Al-Haideri H.H. and Hassan F.M. (2019). Detection of antibiotics in drinking water treatment plants in Baghdad City, Iraq. Advances in Public Health, 2019, 7851354.

Mahmoud I.Y., Al-Bahry S.N. and Al-Musharafi S.K. (2013). Fresh water habitat pollution by treated sewage effluent in relation to multiple-antibiotic-resistant bacteria. APCBEE Procedia, 363-367.

Mao D. (2015). Prevalence and proliferation of antibiotic resistance genes in two municipal wastewater treatment plants. Water Research, 458-466. 
Marie-Claire Danner A.R., Behrends V. and Reiss J. (2019). Antibiotic pollution in surface fresh waters: Occurrence and effects. Science of the Total Environment.

Mcene G., Barron L., Kelleher B., Paull B. and Quinn B. (2014). A year-long study of the spatial occurrence and relative distribution of pharmaceutical residues in sewage e uent, receiving marine waters and marine bivalves. Science of the Total Environment, 476-477, 317-326.

Michael I., Rizzo L., McArdell C.S., Manaia C.M., Merlin C., Schwartz T., Dagot C. and Fatta-Kassinos D.J. (2013). Urban wastewater treatment plants as hotspots for the release of antibiotics in the environment: a review. Water Research, 957-995.

Milić N., et al. (2013). Occurrence of antibiotics as emerging contaminant substances in aquatic environment. International Journal of Environmental Research, 23(4), 296-310.

Moges F., Endris M., Belyhun Y. and Worku W. (2014). Isolation and characterization of multiple drug resistance bacterial pathogens from waste Water in Hospital and non-hospital environments. Northwest Ethiopia. BMC Research Notes.

Moles S., Mosteo R., Gómez J., Szpunar J., Gozzo S., Castillo J.R. and Ormad M.P. (2020). Towards the removal of antibiotics detected in wastewaters in the POCTEFA territory: Occurrence and $\mathrm{TiO}_{2}$ photocatalytic pilot-scale plant performance. Water, 12.

Mustapha A., Tijani I., Bello H.S. and Ismail H.Y. (2016). Resistance profiles of bacteria isolated from wastewater in the university of Maiduguri teaching Hospital. Journal of Biotechnology Research, 49-54.

Nain V.K. (2015). Antibiotic resistance pattern in bacterial isolates obtained from different Water samples of Delhi region. Journal of Undergraduate Research and Innovation, 219-227.

Nuamah L.A., et al. (2020). Constructed wetlands, status, progress, and challenges. The need for critical operational reassessment for a cleaner productive ecosystem. Journal of Cleaner Production, 269, 122340.

Nuñez L., (2016). Hospital effluent constitutes a source of vancomycin-resistant enterococci.

Oetken M., Nentwig G., Löffler D., Ternes T. and Oehlmann J. (2005). Effects of pharmaceuticals on aquatic invertebrates. Part I. The antiepileptic drug carbamazepine. Archives of Environmental Contamination and Toxicology, 353-361.

Olaniran A.O., Naicker K. and Pillay B. (2009). Antibiotic resistance profiles of Escherichia coli isolates from river sources in Durban, South Africa. World Journal of Microbiology and Biotechnology, 1743-1749.

Ollivier J., Schacht D., Kindler R., Groeneweg J., Engel M. and Wilke B.M. (2013). Effects of repeated application of sulfadiazine-contaminated pig manure on the abundance and diversity of ammonia and nitrite oxidizers in the rootrhizosphere complex of pasture plants under field conditions. Frontiers in Microbiology.

Pan S.F., Zhu M.P., Chen J.P., Yuan Z.H., Zhong L.B. and Zheng Y.M. (2015). Separation of tetracycline from wastewater using forward osmosis process with thin film composite membrane-Implications for antibiotics recovery. Separation and Purification Technology, 153, 76-83.

Parde D., et al. (2021). A review of constructed wetland on type, treatment and technology of wastewater. Environmental Technology \& Innovation, 21, 101261.
Peng L., Hua Y., Cai J., Zhao J., Zhou W. and Zhu D. (2014). Effects of plants and temperature on nitrogen removal and microbiology in a pilot-scale integrated vertical-flow wetland treating primary domestic wastewater. Ecological Engineering, 285-290.

Perron G.G., et al. (2015). Functional characterization of bacteria isolated from ancient arctic soil exposes diverse resistance mechanisms to modern antibiotics. PLoS One, 10(3), e0069533.

Polianciuc S.I., et al. (2020). Antibiotics in the environment: causes and consequences. Medicine and Pharmacy Reports, 93(3), 231-240.

Priyankaa N. (2015). Bacterial dynamics in antibiotic wastewater treatment - a review bacterial dynamics in antibiotic wastewater treatment - a review. International Journal on Occupational Health \& Safety, Fire \& Environment - Allied Sciences, 1-8.

Rajan R.J., Sudarsan J.S. and Nithiyanantham S. (2020). Efficiency of constructed wetlands in treating E. coli bacteria present in livestock wastewater. International Journal of Environmental Science and Technology, 17(4), 2153-2162.

Rajan R.J., Sudarsan J.S. and Nithiyanantham S. (2019). Microbial population dynamics in constructed wetlands: Review of recent advancements for wastewater treatment. Environmental Engineering Research, 24(2), 181-190.

Reichel R., Rosendahl I., Peeters E.T., Focks A., Groeneweg J. and Bierl R. (2013). Effects of slurry from sulfadiazine- (SDZ) and difl oxacin-(DIF) medicated pigs on the structural diversity of microorganisms in bulk and rhizosphere soil. Soil Biology and Biochemistry, 82-91.

Rowe W.P.M. (2017). Overexpression of antibiotic resistance genes in Hospital effluents over time. Journal of Antimicrobial Chemotherapy, 1617-1623.

Sandoval L., et al. (2016). Role of wetland plants and use of ornamental flowering plants in constructed wetlands for wastewater treatment: a review. 9(4), 685.

Sanjrani M.A., Zhou B., Zhao H., Zheng Y.P., Wang Y. and Xia S.B. (2019). The influence of wetland media in improving the performance of pollutant removal in water treatment: a review. Applied Ecology And Environmental Research, 38033818.

Sanjrani M.A., Zhou B., Zhao H., Zheng Y.P., Wang Y. and Xia S.B. (2019). Treatment of wastewater with constructed wetlands systems and plants used in this technology-a review. Applied Ecology and Environmental Research, 18(1), 107-127.

Scholz M. and Lee B.H. (2005). Constructed wetlands: a review. International Journal of Environmental Studies, 421-47.

Shelef O., Gross A. and Rachmilevitch S. (2013). Role of plants in a constructed wetland: current and new perspectives. Water, 5(2).

Sidrach-Cardona R. and Becares E. (2013). Fecal indicator bacteria resistance to antibiotics in experimental constructed wetlands. Ecological Engineering, 107-111.

Stottmeister U., et al. (2003). Effects of plants and microorganisms in constructed wetlands for wastewater treatment. Biotechnology Advances, 22(1), 93-117.

Tang S., et al. (2020). Microbial coupling mechanisms of nitrogen removal in constructed wetlands: A review. Bioresource Technology, 314, 123759.

Thai P.K., Binh V.N., Nhung P.H., Nhan P.T., Hieu N.Q., Dang N.T., Tam N.K. and Anh N.T. (2018). Occurrence of antibiotic 
residues and antibiotic-resistant bacteria in effluents of pharmaceutical manufacturers and other sources around Hanoi, Vietnam. Science of the Total Environment, 645, 393400.

Thiele-Bruhn S. and Beck I.C. (2005). Effects of sulfonamide and tetracycline antibiotics on soil microbial activity and microbial biomass. Chemosphere, 457-465.

Thuy H.T. and Loan T.T. (2011). Antibiotic contaminants in coastal wetlands from Vietnamese shrimp farming. Environmental Science and Pollution Research, 835-841.

Tong X.-N., et al. (2020). Effects of antibiotics on microbial community structure and microbial functions in constructed wetlands treated with artificial root exudates. Environmental Science: Processes \& Impacts, 22(1), 217-226.

Van Boeckel T.P., et al. (2015). Global trends in antimicrobial use in food animals. Proceedings of the National Academy of Sciences of the United States of America, 112(18), 56495654.

Vaz-Moreira I., Nunes O.C. and Manaia C.M. (2014). Bacterial diversity and antibiotic resistance in Water habitats: searching the Links with the human microbiome. FEMS Microbiology Reviews, 761-778.

Verlicchi P., Al Aukidy M. and Zambello E. (2012). Occurrence of pharmaceutical compounds in urban wastewater: removal, mass load and environmental risk after a secondary treatment-a review. Science of the Total Environment, 123-55.

Vymazal J. (2013). Emergent plants used in free water surface constructed wetlands: A review. Ecological Engineering, 61, 582-592.

Vymazal J. (2011). Plants used in constructed wetlands with horizontal subsurface flow: a review. Hydrobiologia, 674(1), 133-156.

Wang H., Sheng L. and Xu J.(2021). Clogging mechanisms of constructed wetlands: A critical review. Journal of Cleaner Production, 295, 126455.

Wang P., et al.(2016). A hardy plant facilitates nitrogen removal via microbial communities in subsurface flow constructed wetlands in winter. Scientific Reports, 6(1), 33600.

Watkinson A.J., Murby E.J., Kolpin D.W. and Costanzo S.D. (2009). The occurrence of antibiotics in an urban watershed: from wastewater to drinking water. Science of the Total Environment, 2711-2723.

Watkinson A.J., Murby E.J. and Costanzo S.D. (2007). Removal of antibiotics in conventional and advanced wastewater treatment: Implications for environmental discharge and wastewater recycling. Water Research, 41(18), 4164-4176.

Williams M.R., Stedtfeld R.D., Guo X. and Hashsham S.A. (2016). Antimicrobial resistance in the environment. Water Environment Research, 1951-1967.

Williams-Nguyen J., Brett Sallach J. and Bartelt-Hunt S. (2016). Antibiotics and antibiotic resistance in agroecosystems: State of the science. Journal of Environmental Quality, 45(2).

Wu X., Conkle J.L. and Gan J. (2012). Multi-residue determination of pharmaceutical and personal care products in vegetables. Journal of Chromatography. A, 78-86.

$\mathrm{Wu}$ H., et al. (2015). A review on the sustainability of constructed wetlands for wastewater treatment: Design and operation. Bioresource Technology, 175, 594-601.

Xiaoyan T., Suyu W., Yang Y., Ran T., Yunv D., Dan A. and Li L. (2015). Removal of six phthalic acid esters (PAEs) from domestic sewage by constructed wetlands. Chemical Engineering Journal, 198-205.

Xu W., Zhang G., Li X., Zou S., Li P., Hu Z. and Li J. (2007). Occurrence and elimination of antibiotics at four sewage treatment plants in the Pearl River Delta (PRD). South China. Water Research, 4526-4534.

Xue B., et al. (2013). Antibiotic contamination in a typical developing city in south China: Occurrence and ecological risks in the Yongjiang River impacted by tributary discharge and anthropogenic activities. Ecotoxicology and Environmental Safety, 92, 229-236.

Yan Q., Zhang Y.X., Kang J., Gan X.M., Xu Y.P., Guo J.S. and Gao X. (2015). A preliminary study on the occurrence of pharmaceutically active compounds in the river basins and their removal in two conventional drinking water treatment plants in Chongqing, China. Clean-Soil, Air, Water, 794-803.

Yang Y. (2017). Antibiotic resistance genes in lakes from middle and lower reaches of the Yangtze River, China: effect of Land use and sediment characteristics. Chemosphere, 19-25.

Yidong G.U., Bo W.A., Yongxia G.A., Wen L.I., Xiaoli Z.H., Huang X. and Jianghua Y.U. (2017). Occurrence and fate of antibiotics in the aqueous environment and their removal by constructed wetlands in china: a review. Pedosphere, 27(1), 42-51.

Zhang D., Gersberg R.M., Ng W.J. and Tan S.K. (2014). Removal of pharmaceuticals and personal care products in aquatic plant-based systems: a review. Environmental Pollution, 620-639.

Zhang Q.Q., Ying G.G., Pan C.G., Liu Y.S. and Zhao J.L. (2015). Comprehensive evaluation of antibiotics emission and fate in the river basins of China: Source analysis, multimedia modeling, and linkage to bacterial resistance. Environmental Science Technology, 6772-6782.

Zhang H., et al. (2013). Fate of antibiotics during wastewater treatment and antibiotic distribution in the effluentreceiving waters of the Yellow Sea, northern China. Marine Pollution Bulletin, 73(1), 282-290.

Zhang S., et al. (2011). Constructed wetland revealed efficient sulfamethoxazole removal but enhanced the spread of antibiotic resistance genes. Molecules, 25(4), 834.

Zhao Y., et al. (2020). Constructed treatment wetland: Glance of development and future perspectives. Water Cycle, 1, 104112.

Zhou L.J., Ying G.G., Liu S., Zhao J.L., Yang B., Chen Z.F. and Lai H.J. (2013). Occurrence and fate of eleven classes of antibiotics in two typical wastewater treatment plants in South China. Science of the Total Environment.

Zhou L.J., Ying G.G., Zhao J.L., Yang J.F., Wang L., Yang B. and Liu S. (2011). Trends in the occurrence of human and veterinary antibiotics in the sediments of the Yellow River, Hai River and Liao River in northern China. Environmental Pollution, 1877-1885.

Zhou L.J., Ying G.G., Liu S., Zhao J.L., Yang B., Chen Z.F. and Lai H.J. (2013). Occurrence and fate of eleven classes of antibiotics in two typical wastewater treatment plants in South China. Science of the Total Environment, 365-376. 